\title{
PERBANDINGAN CEDERA OLAHRAGAPADA ATLET BELADIRI TAEKWONDO DAN ATLET BELADIRI JUDO SELAMA BERADA DI PUSAT PELATIHAN DAN LATIHAN PELAJAR (PPLP) RAGUNAN
}

\author{
Ardiyansyah Muhammad ${ }^{1}$ \\ dr. Ruliando Hasea Purba, MARS, SpRM², Dr. Yasep Setiakarnawijaya, SKM, M.Kes ${ }^{2}$ \\ ${ }^{1}$ Program Studi Ilmu Keolahragaan \\ ${ }^{2}$ Fakultas Ilmu Keolahragaan Universitas Negeri Jakarta, Kampus B, Jakarta
}

\begin{abstract}
Abstrak: Penelitian ini bertujuan untuk mengetahui perbandingan cedera olahraga pada atlet beladiri Taekwondo dan atlet beladiri Judo selama berada di Pusat Pendidikan dan Latihan Pelajar (PPLP) Ragunan. Penelitian ini dilakukan pada bulan Februari sampai selesai tahun 2012 di Pusat Pendidikan dan Latihan Pelajar (PPLP) Ragunan. Adapun yang menjadi objek penelitian ini adalah atlet beladiri taekwondo, atlet beladiri judo, dan dokter poliklinik di Pusat Pendidikan dan Latihan Pelajar (PPLP) Ragunan yang pernah mengalami cedera olahraga pada saat berolahraga. Metode yang digunakan pada penelitian ini adalah metode penelitian deskriptif dengan teknik survey, yaitu dengan wawancara. Berdasarkan hasil penelitian, dapat diperoleh kesimpulan yaitu: Atlet taekwondo yang mengalami cedera olahraga ada 22 atlet $(95.65 \%)$, dan atlet judo yang mengalami cedera olahraga ada 18 atlet (100\%). Dari 22 atlet taekwondo yang mengalami cedera olahraga, didapat 92 kasus cedera olahraga, dan dari 18 atlet judo yang cedera didapat 60 kasus cedera olahraga. Atlet taekwondo paling banyak mengalami cedera pada tubuh bagian bawah yaitu ada 66 kasus cedera (71.74\%), dan pada atlet judo paling banyak mengalami cedera pada tubuh bagian atas yaitu ada 40 kasus (66.67\%). Atlet taekwondo dan atlet judo paling banyak mengalami cedera olahraga pada saat latihan, pada atlet taekwondo ada 80 kasus (86.96\%), dan pada atlet judo ada 48 kasus (80\%).atlet taekwondo dan atlet judo paling banyak mengalami cedera olahraga karena faktor internal violence, pada atlet taekwondo ada 62 kasus $67.40 \%$ ), dan pada atlet judo ada 30 kasus (50\%). Atlet taekwondo dan atlet judo paling banyak menangani cedera olahraga dengan pergi ke poliklinik PPLP Ragunan, pada atlet taekwondo ada 80 kasus $(86.96 \%)$ dan pada atlet judo ada 50 kasus $(83.33 \%)$. Atlet taekwondo paling banyak mengalami jenis cedera otot \& tendo yaitu ada 36 kasus (45\%), dan atlet judo paling banyak mengalami jenis cedera ligament dan sendi, yaitu masing-masing ada 20 kasus (40\%). Atlet taekwondo dan atlet judo paling banyak mengalami cedera ringan, pada atlet taekwondo ada 58 kasus $(72.5 \%)$ dan pada atlet judo ada 30 kasus (60\%). Atlet taekwondo dan atlet judo paling banyak mengalami cedera kronis, pada atlet taekwondo ada 46 kasus $(57.5 \%)$ dan pada atlet judo ada 29 kasus (58\%).
\end{abstract}

Kata kunci : Cedera olahraga, atlet beladiri taekwondo, atlet beladiri judo, pusat pelatihan dan latihan pelajar.

\section{PENDAHULUAN}

Olahraga bertujuan untuk menyehatkan badan, memberikan kebugaran jasmani selama cara-cara melakukannya sudah dalam kondisi yang benar. Kegiatan olahraga sekarang ini telah benar-benar menjadi bagian masyarakat kita, baik pada

masyarakat atau golongan dengan sosial ekonomi yang rendah sampai yang paling baik, telah menyadari kegunaan akan pentingnya latihan-latihan yang teratur untuk kesegaran dan kesehatan jasmani dan rohani. Seseorang melakukan olahraga dengan 
tujuan untuk mendapatkan kebugaran jasmani, kesehatan maupun kesenangan bahkan ada yang sekedar hobi, sedangkan atlet baik amatir dan profesional selalu berusaha mencapai prestasi sekurangkurangnya untuk menjadi juara. Apakah semua macam olahraga bisa menimbulkan cedera? Cedera yang dialami tergantung dari olahraganya, misalnya olahraga sepak bola, otomotif, beladiri, dan lain-lain tentu memberikan resiko cedera yang berbedabeda.

Olahraga bela diri merupakan olahraga yang sangat bermanfaat, bukan hanya membuat orang itu sehat tetapi juga dapat digunakan untuk pertahanan diri bila ada orang lain yang berniat jahat. Olahraga bela diri di Indonesia sangat banyak, ada yang asli dari Indonesia yaitu pencak silat dan tarung bebas, dan ada juga dari luar Indonesia seperti taekwondo, karate, judo, kempo, wushu, dan banyak lagi. Selain untuk olahraga, bela diri juga bertujuan lain yaitu seni. Dapat dilihat dari kejuaraankejuaraan bela diri yang tidak hanya berbentuk pertarungan tetapi juga keindahan dalam mengeluarkan jurus-jurus dari bela diri tersebut.

Olahraga bela diri dapat berguna bila dilakukan dengan cara yang baik dan benar. Olahraga bela diri sangat berbahaya bila dilakukan untuk hal-hal yang tidak baik. Semua olahraga mempunyai dampak yang positif dan juga negatif. Sama halnya dengan olahraga bela diri, dampak negatifnya adalah dapat menimbulkan cedera. Sebab dari cedera sangat beragam, bisa dari dalam diri kita sendiri yaitu dengan melakukan gerakan yang tidak sempurna ataupun dari lingkungan sekitar seperti lawan pada saat bertanding. Olahraga bela diri merupakan olahraga yang mempunyai sifat body contact atau kontak fisik, jadi olahraga ini sangat rentan terkena cedera.

Tekwondo dan judo merupakan bagian dari olahraga bela diri. Kedua olahraga tersebut mempunyai kriteria bertanding yang sangat berbeda. Seperti pada taekwondo, olahraga beladiri ini sedikit sekali bantingan bahkan nyaris tidak ada sama sekali tetapi banyak menggunakan tendangan dan pukulan dalam menyerang lawan. Lain halnya dengan judo, olahraga bela diri ini kebalikan dari taekwondo yaitu menyerang lawan dengan cara membanting atau menjatuhkan untuk mendapat point tanpa adanya tendangan ataupun pukulan. Oleh karena perbedaan bertanding tersebut, maka perbedaan cedera yang didapat juga pasti berbeda. Pada atlet taekwondo dan judo Pusat Pendidikan dan Latihan Pelajar (PPLP) ragunan yang dipersiapkan untuk pertandingan besar seperti kejuaraan tingkat nasional ataupun internasional, pengetahuan tentang meminimalisir cedera sudah ditanamkan agar atlet dapat menjadi juara tanpa adanya masalah atau gangguan dari cedera. Baik pada saat berlatih maupun bertanding. Bagaimanapun cedera olahraga merupakan salah satu faktor penyebab jatuhnya prestasi dan keberhasilan seorang atlet.

Oleh karena itu, peneliti ingin meneliti tentang cedera olahraga pada atlet cabang taekwondo dan judo selama berada di Pusat Pendidikan dan Latihan Pelajar (PPLP) Ragunan, yang secara jelas bahwa cedera olahraga merupakan salah satu kendala atau masalah yang menyebabkan merosotnya prestasi olahraga di DKI Jakarta.

Tinjauan Pustaka. Cedera menurut Kamus Besar Bahasa Indonesia adalah cacat (luka) sedikit. Sedangkan luka menurut Budi Rahardjo adalah rusaknya keutuhan jaringan lunak oleh karena ruda paksa atau juga bisa dikatakan terputusnya jaringan tubuh karena kekerasan. Penyebab dari luka pada umumnya karena (1) benda tumpul, tajam atau mekanis, (2) benda panas atau suhu tinggi. Berdasarkan akibatnya luka dapat digolongkan menjadi luka terbuka dan luka tertutup. Luka terbuka yaitu lapisan jaringan yang paling luar tidak utuh lagi, sehingga terlihat jaringan dibawahnya, sedangkan luka tertutup yaitu jenis luka yang kerusakannya terdapat dibawah kulit. Cedera menurut Hardianto Wibowo dalam bukunya, Pencegahan dan Penatalaksanaan Cedera Olahraga ialah segala macam cedera 
yang timbul, baik pada waktu latihan maupun pada waktu berolahraga (pertandingan) ataupun sesudah pertandingan. Jadi, cedera olahraga adalah cacat (luka) atau rusaknya susunan sel tubuh maupun system yang bekerja ditubuh yang disebabkan oleh kegiatan olahraga, baik pada saat latihan ataupun pada saat pertandingan.

Reaksi tubuh bila terkena cedera akan menimbulkan gejala-gejala atau tanda-tanda sebagai berikut: panas (kalor), merah (rubor), nyeri atau sakit (dolor), bengkak (tumor), tidak bisa dipergunakan lagi (fungsiolesi). Jadi, bila seseorang terkena cedera mereka pasti mengetahuinya karena reaksi yang terjadi di dalam tubuhnya.

Dengan melihat pengertian dari cedera olahraga maka semua bagian tubuh dapat mengalami cedera. Berikut ini adalah bagian tubuh yang sering terkena cedera:

1. Kulit

Kulit terdiri atas dua bagian, yaitu kulit bagian dalam dan kulit bagian luar. Kulit yang berhubungan langsung dengan dunia luar disebut epidermis, sedangkan kulit bagian dalam disebut dermis. Cedera yang sering terjadi adalah lecet, terkelupasnya kulit, terpotong, maupun luka tusuk.

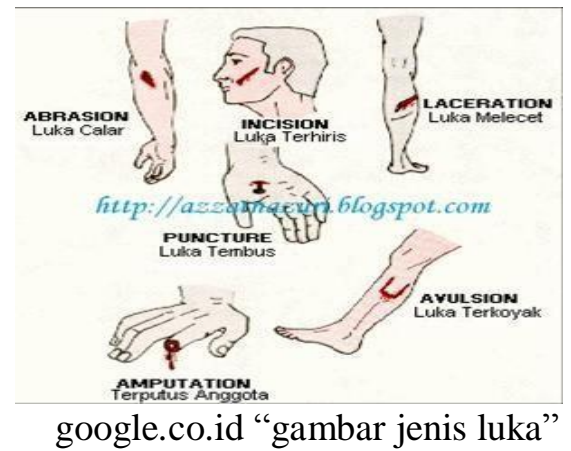

Gamb ar 1. Ceder a pada kulit Sumb er: www.

\section{Otot/tendo dan ligament}

Cedera pada otot/tendo dan ligament ada dua yaitu Strain adalah cedera yang terjadi pada otot dan tendo dan Sprain adalah cedera yang terjadi pada ligament. Strain dan sprain dapat dibagi menjadi tiga tingkatan yaitu:

a. Strain/Sprain derajat 1 (First Degree Strain/Sprain) yaitu cedera yang paling ringan, dimana cedera yang terjadi hanya mengenai beberapa serabut otot/tendo, atau ligament yang robek dan disertai sedikit pembengkakan dan sedikit rasa nyeri.

b. Strain/Sprain derajat 2 (Second Degree Strain/Sprain) yaitu cedera yang terjadi adalah robeknya sebagian besar serabut otot/tendo serta ligament, dapat sampai setengah jumlah serabut otot yang robek.

c. Strain/Sprain derajat 3 (Thrid Degree Strain/Sprain) kadang disebut robek total (Complete Rupture) yaitu cedera yang terjadi dimana serabut otot/tendo ataupun ligament sudah putus (robek total), atau hampir putus, lebih dari setengah jumlah serabut otot yang robek.

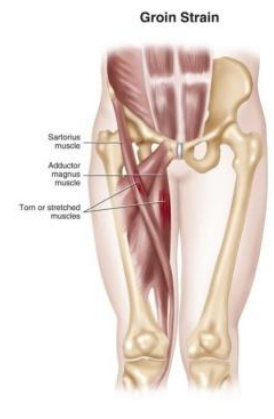

Gambar 2. Cedera strain

Sumber: www.google.co.id "gambar cedera strain"

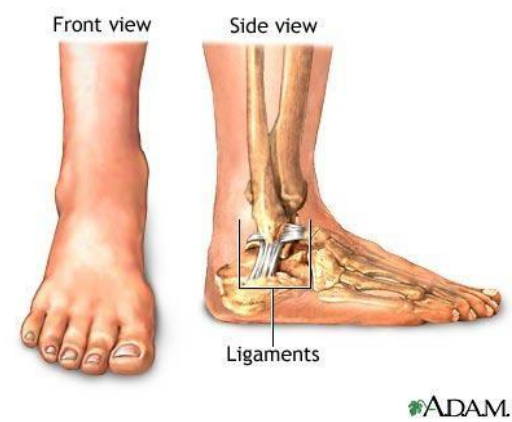

Gambar 3. Cedera sprain

Sumber: www.google.co.id "gambar cedera sprain"

3. Tulang

Cedera pada tulang yang biasa terjadi adalah patah tulang. Patah tulang adalah suatu keadaan dimana tulang retak, pecah/patah. Bentuk dari patah tulang bisa hanya retakan saja, sampai hancur 
berkeping-keping. Patah tulang dibagi menjadi dua macam yaitu,

a. Fraktur sederhana (simple fracture) dimana patah tulang terjadi tidak diikuti dengan robeknya kulit.

b. Fraktur kompleks (compound fracture) ialah fraktur dimana ujung tulang menonjol keluar melewati kulit. Jenis fraktur kompleks lebih berbahaya daripada fraktur sederhana karena dengan terlukanya kulit maka akan ada bahaya infeksi yaitu masuknya kuman-kuman penyakit ke dalam jaringan.

4. Sendi dan Tulang Rawan Sendi

Sendi adalah hubungan diantara dua buah ujung tulang yang berfungsi sebagai sebuah engsel, sehingga tulang yang satu dapat bergerak terhadap tulang yang lainnya. Cedera yang mungkin terjadi pada sendi adalah dislokasi dan subluksasi. Dislokasi adalah terlepasnya tulang dari kesatuan sendi secara total (lepas total). Sedangkan subluksasi adalah terlepasnya tulang dari kesatuan sendi tetapi tidak total. Cedera pada kapsul artikularis/simpai sendi. Kapsula artikularis terdiri atas:

a. Lapisan luar (stratum fibrosum), dan b. Lapisan dalam (stratum sinovialis).

Tulang rawan adalah tulang yang berwarna putih, kuat dan liat, serta tidak mengandung pembuluh darah dan saraf melapisi ujung tulang dalam persendian dan melindungi tulang tersebut agar tidak bergesekan antara satu sama lain. Cedera yang mungkin terjadi pada tulang rawan adalah retak, robek, atau menjadi berkepingkeping.

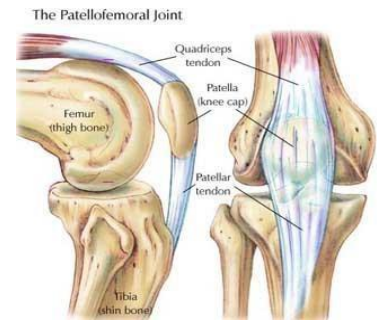

Gambar 4. Cedera pada sendi

Sumber: www.google.co.id "gambar articulation injuries"

Menurut Hardianto Wibowo, cedera dibagi berdasarkan berat ringannya yaitu cedera berat dan cedera ringan. Cedera berat adalah cedera serius yang diikuti adanya kerusakan jaringan pada tubuh kita. Misalnya robek otot, ligament, atau patah tulang. Sedangkan cedera ringan adalah cedera yang tidak diikuti kerusakan pada jaringan tubuh kita. Misalnya, kekakuan otot dan kelelahan.

Pada "kuliah pengantar cedera olahraga" oleh Jeanne D.L. Tobing, ada dua jenis cedera pada atlet menurut waktu terjadi atau sifatnya yaitu, cedera akut dan cedera kronis. Cedera akut adalah suatu cedera yang secara iba-tiba dan terjadi dalam beberapa jam yang lalu. Tanda dan gejalanya yaitu sakit, kemerahan, kulit hangat, bengkak, dan inflasi. Cedera kronis adalah suatu cedera yang berkembang secara lambat. Gejalanya hilang timbul dan menyebabkan nyeri tumpul dan sakit. Biasanya karena over-use atau cedera akut yang tidak sembuh sempurna. Jadi, cedera akut adalah cedera secara tiba-tiba dan terjadi beberapa jam yang lalu, cedera akut dapat disembuhkan. Sedangkan cedera kronis adalah cedera yang berkembang secara lambat, cedera ini sulit untuk disembuhkan (cedera kambuhan).

Segala macam cedera yang timbul, baik pada waktu latihan maupun pada waktu berolahraga atau pertandingan ataupun sesudahnya. Dapat dilihat dari pengertian diatas bahwa cedera olahraga yang terjadi pada atlet terjadi pada saat berlatih dan bertanding. Atlet lebih banyak mendapatkan cedera olahraga pada saat berlatih dibandingkan pada saat bertanding. Karena dalam olahraga prestasi, latihan akan memerlukan banyak waktu dibandingkan bertanding. Adapun sebab-sebab lain adalah seperti sarana dan pra-sarana yang kurang memadai di tempat latihan, contohnya matras yang dipakai berlatih kurang lebih baik dibanding matras yang dipakai pada saat pertandingan. Sebab lain yang terjadi adalah pada pertandingan, latihan pertandingan dipastikan berbeda dengan pertandingan resmi. Latihan pertandingan biasanya tidak begitu serius malah ada juga yang seenaknya. Kejadian- 
kejadian yang tidak terduga seperti pada saat pertandingan resmi salah mengikuti kelas bertanding.

Berdasarkan macamnya cedera, maka cedera olahraga dapat dibagi atas sebabsebabnya cedera. Sebab-sebab yang berasal dari luar (external violence) adalah cedera yang timbul/ terjadi karena pengaruh atau sebab yang berasal dari luar, sebab-sebab yang berasal dari dalam (internal violence) adalah cedera yang terjadi karena koordinasi otot-otot dan sendi yang kurang sempurna, sehingga menimbulkan gerakan-gerakan yang salah, sehingga menimbulkan cedera, dan yang terakhir adalah Pemakaian yang terus-menerus/ terlalu lelah (over-use) adalah cedera yang timbul karena pemakaian otot yang berlebihan atau terlalu lelah. Cedera karena over-use menempati 1/3 dari cedera olahraga yang terjadi. Biasanya cedera akibat over-use terjadinya secara perlahan-lahan (bersifat kronis).

Pengobatan cedera segera setelah terjadi cedera olahraga (0-24 jam) adalah dengan metode RICE (Rest, Ice, Compression, dan Elevation) yang diberikan segera mungkin setelah mengalami cedera olahraga. Adapun pengertian RICE (Rest, Ice, Compression, dan Elevation).

1. Rest (istirahat) adalah mengistirahatkan bagian yang terkena cedera, tidak boleh dipakai/ digerakkan yang bertujuan untuk menghentikan pendarahan dan mengurangi pembengkakan.

2. Ice (es) ialah kompres dingin dengan menggunakan es yang bertujuan untuk menghentikan pendarahan (memperlambat aliran darah), mengurangi pembengkakan, mengurangi rasa sakit. Kompres dingin kurang berpengaruh terhadap bagian yang bersifat dalam.

3. Compression (balut tekan) adalah suatu ikatan yang terbuat dari bahan yang elastis yang bertujuan untuk mengurangi pembengkakan akibat dari ikatan tersebut dan untuk mengurangi pergerakan yang terkena cedera.

4. Elevation (ditinggikan) yaitu meninggikan bagian yang cedera lebih tinggi dari jantung yang bertujuan agar pendarahan berhenti dan pembengkakan berkurang.

Setelah 24 jam dapat dilakukan kompres panas, massage, dan lain- lain. Kompres panas bisa dilakukan setelah bengkak sudah tidak bertambah. Tujuan kompres panas adalah untuk menceraiberaikan cairan plasma darah yang keluar dan masuk disekitar tempat yang cedera. Taekwondo berasal dari bahasa Korea yang terdiri dari tiga suku kata yaitu tae artinya kaki/ menghancurkan dengan teknik tendangan, kwon artinya tangan/ menghantam dan mempertahankan diri dengan teknik tangan, dan $d o$ artinya seni/cara mendisiplinkan diri. Taekwondo dapat diartkan sebagai seni bela diri yang menggunakan tangan dan kaki. Taekwondo merupakan seni beladiri yang menggunakan tangan dan kaki yang beraneka ragam dan secara luas telah diakui kelebihan-kelebihannya.

Tendangan di dalam Taekwondo sangat beragam dan memiliki maksud dan tujuan yang berbeda-beda, oleh karena itu setiap sabeum, sebutan untuk pelatih Taekwondo, harus menjelaskan kepada jeja, sebutan untuk pelajar Taekwondo, pada saat latihan. Taekwondo adalah cabang olahraga beladiri yang full body contact mengajarkan pukulan dan tendangan sebagai upaya untuk mengatasi serangan dari pihak lain. Tiga materi terpenting dalam berlatih Taekwondo adalah rangkaian jurus atau disebut Poomse, pemecahan benda keras atau disebut $K y u k p a$, dan pertarungan atau disebut Kyoruki. Olahraga Taekwondo yang dikembangkan untuk prestadi di Indonesia adalah Kyoruki dan Poomse.

Gerakan dasar Taekwondo (Ki Bon Do Jak) terbentuk dari kombinasi berbagai teknik gerakan menyerang dan bertahan. Dasar-dasar Taekwondo terdiri atas 5 komponen, yaitu:

1. Keupso (bagian tubuh yang menjadi sasaran),

2. Bagian tubuh yang digunakan untuk menyerang dan bertahan,

3. Seogi (sikap kuda-kuda),

4. Makki (tangkisan), dan

5. Kongkyok Kisul (teknik serangan). 
Taekwondo memiliki tingkatantingkatan bagi setiap orang yang mengikutinya yaitu sabuk yang digunakan ketika memakai seragam Taekwondo atau disebut dobook. Sabuk dalam Taekwondo memiliki arti dari setiap masing-masing sabuk yaitu:

1. Putih

Melambangkan kesucian, awal/dasar dari semua warna, permulaan. Mempelajari jurus taeguk satu.

2. Kuning

Melambangkan bumi, disinilah mulai ditanamkan dasar-dasar Taekwondo dengan kuat. Mempelajari jurus dasar taeguk dua dan tiga.

3. Hijau

Melambangkan hijaunya pepohonan, pada saat inilah dasar.

Taekwondo mulai ditumbuhkembangkan . Mempelajari jurus taeguk empat dan lima. Sebelum naik ke sabuk biru biasanya naik ke sabuk hijau strip biru terlebih dahulu.

4. Biru

Melambangkan birunya langit yang menyelimuti bumi dan seisinya, member arti bahwa kita harus mulai mengetahui apa yang telah kita pelajari. Mempelajari taeguk enam dan tujuh. Sebelum naik sabuk merah biasanya naik sabuk biru strip merah terlebih dahulu.

5. Merah

Melambangkan matahari artinya bahwa kita mulai menjadi pedoman bagi orang lain dan mengingatkan harus dapat mengontrol setiap sikap dan tindakan kita. Mempelajari taeguk delapan, sembilan, dan sepuluh. Sebelum naik sabuk hitam biasanya naik sabuk merah strip dua dan merah strip satu terlebih dahulu.

6. Hitam

Melambangkan akhir, kedalaman, kematangan dalam berlatih dan penguasaan diri kita dari takut dan kegelapan. Hitam memiliki tahapan dari dan satu hingga dan sepuluh. Taekwondo tidak hanya mengajarkan aspek keterampilan fisik semata, seperti bertarung, melainkan juga sangat menekankan pada aspek disiplin mental dan etika yang baik bagi orang yang sungguh-sungguh mempelajarinya dengan benar. Berarti dalam mempelajari Taeokwondo terdapat tiga aspek filosofi yang mendalam, hal ini terkait dengan manusia yang terdapat tiga bagian yang berbeda dalam diri mereka yaitu: pikiran (aspek intelektual), raga (aspek fisik), dan jiwa (aspek mental).

Judo adalah seni beladiri, olahraga, dan filosofi yang berakar dari Jepang. Judo berasal dari dua suku kata yaitu $j u$ yang berarti lembut dan $d o$ yang berarti cara, jadi judo adalah cara yang lembut. Judo dikembangkan dari seni beladiri kuno Jepang yang disebut Jujutsu. Pemain judo disebut juga judoka atau pejudo. Saat ini judo merupakan cabang olahraga resmi Olimpiade. Persatuan Judo Seluruh Indonesia (PJSI) menjelaskan:

Judo adalah olahraga yang lembut kendatipun juga diperlukan kekuatan. Tujuan membanting lawan bukanlah untuk menghancurkannya. Keselamatan lawan harus diperhitungkan itulah sebabnya maka tangan dari lawan (uke) tidak boleh dilepas tatkala membanting hingga lawan menjadi cedera. Jadi banting-membanting dalam judo bukanlah untuk tujuan merusak, melainkan untuk jutuan olahraga dan harus pula mengandung unsur keindahan.

Dalam suatu pertandingan, judo dipertandingkan dengan peraturan- peraturan yang telah ditetapkan dalam waktu 4-5 menit di atas lantai dalam ruangan dilapisi matras (tatame) berwarna hijau dengan ukuran 16x16 m. setiap pejudo harus mengenakan pakaian judo (judogi) berwarna putih atau keputih-putihan yang terdiri dari baju (umagi), celana (shita baki), serta mengenakan sabuk (obi) sesuai dengan tingkatannya. Pertandingan dilaksanakan dalam kategori kelas yang ditentukan atas dasar berat badan. Teknik dalam pertandingan judo.

1. Teknik bantingan judo (nage waza),

2. Teknik kuncian judo (katame waza),

3. Teknik menyerang (atemi waza),

4. Teknik terlarang. 
Total teknik terlarang berjumlah 31 (32 untuk perempuan). Judoka akan dikenai empat tingkatan sanksi, tergantung seberapa berat pelanggaran yang dilakukan. Untuk tiap-tiap jenis pelanggaran, pertandingan dihentikan sejenak dan kedua judoka kembali ke garis masing-masing. Berikut adalah empat tingkatan sangsi:

a. Pelanggaran ringan (shido)

b. Pelanggaran kecil (chui)

a. Pelanggaran berat (keikoku)

d.Pelanggaran serius (hansoku make)

Ketentuan-ketentuan pakaian judo:

1. Baju (umagi)

a. Panjang baju harus cukup panjang menutupi paha dan minimal harus mencapai jari-jari tangan apabila tangan terentang pada kedua sisi badan.

b. Baju harus cukup lebar untuk menutupi bagian daerah rusuk dengan kelebihan minimal $20 \mathrm{~cm}$. Lengan baju minimal harus mencapai pergelangan tangan. Harus ada jarak/ruangan 10-15 cm diantara lengan baju dengan lengan termasuk ikatan-ikatan sepanjang lengan baju.

c. Para peserta wanita harus mengenakan kaos oblong di bawah baju judonya, berwarna putih atau keputih-putihan, lengan pendek, cukup kuat dan cukup panjang untuk dimasukan dalam celana.

\section{Celana (shita baki)}

a. Celana harus cukup panjang untuk menitupi kaki dan maksimal harus mencapai mata kaki dan minimal $5 \mathrm{~cm}$ diatas mata kaki.

b. Harus ada jarak/ruangan 10-15 cm antara celana dan kaki termasuk perban-perban-ikatan-ikatan sepanjang celana tersebut.

3. Ikat Pinggang (obi)

Ikat pinggang harus kuat, lebar 4-5 cm, dengan warna sabuk sesuai dengan tingkatannya dipakai sesudah mengenakan judogi, diikatkan pada pinggang dengan simpul segi empat, cukup kencang agar baju tidak terlepas dan cukup panjang untuk dua kali lingkar pinggang dan harus tersisa 20-30 cm pada tiap ujungnya. Teknik dasar judo berawal dari menghilangkan keseimbangan lawan (kuzushi) dengan cara mendorong atau menarik dengan menggunakan dorongan atau tarikan. Setelah lawan mulai hilang keseimbangan, maka masuklah teknik yang dilakukan secara bersamaan yang menjadi satu kesatuan gerakan sehingga menghasilkan teknik bantingan yang sempurna. Bila dilihat dari teknik yang dilakuka, kekuatan dan keseimbangan adalah elemen penting yang harus dimiliki pejudo disamping kemampuan fisik lainnya yang harus diperhatikan juga seperti, kecepatan reaksi, koordinasi, kelincahan, kecepatan, dan daya tahan. Seorang pejudo yang mempunyai kekuatan otot dan keseimbangan yang baik akan sulit dijatuhkan oleh lawan dan memiliki kelebihan dalam melakukan teknik bantingan.

Atlet menurut kamus besar bahasa Indonesia adalah pemain yang mengikuti perlombaan atau pertandingan dalam beradu ketangkasan, kecepatan, keterampian dan kekuatan. Sedangkan menurut Poerwardarminta, atlet merupakan suatu orang yang bersungguh-sungguh gemar berolahraga terutama mengenai kekuatan badan, ketangkasan dan kecepatan berlari, berenang, melompat dan lain-lain.

Pusat Pendidikan dan Latihan Pelajar (PPLP) Ragunan sangat membantu untuk menciptakan atlet-atlet dari berbagai cabang olahraga yang dipertandingkan. Hal ini sesuai dengan Pemprov DKI Jakarta yang ingin mengelola sekolah olahraga ragunan, yang dimana sekolah olahraga ragunan menjadi tumpuan bagi bangsa untuk mencetak bibit-bibit unggul menjadi atlet handal tanpa mengabaikan pendidikan. Didalam sekolah PPLP Ragunan ini, yang tepatnya di Komplek Ragunan, Jln. Haryono RM. Ragunan, Jakarta Selatan membina pelajar-pelajar yang memalui penyeleksian yang ketat. Dengan persyaratan yang begitu selektif sehingga calon peserta pelajar harus mengikuti prosedur yang dikeluarkan panitia penerimaan siswa baru seperti:

1. Siswa berasal dari WNI (Warga Negara Indonesia). 
2. Siswa diutamakan mempunyai prestasi di tingkat nasional.

3. Siswa harus membawa surat usulan atau rekomendasi dari Dinas Pendidikan/ Kepala Badan Pemuda Olahraga/ Dinas Pemuda Olahraga setempat.

4. Siswa membawa surat rekomendasi Pemprov Cabang Olahraga bersangkutan.

Dalam program latihan, pelatih wajib membangun atlet-atlet dengan pengaturan gizi dan pola hidup sehat bagi atlet sangat berperan penting untuk menunjang stabilitas sebagai atlet juara. Pengaturan gizi atlet khususnya tentang pengaturan pola makan sangat penting karena memberikan keuntungan dan manfaat sebagai berikut:

a. Memberikan pengetahuan tentang makanan untuk mempertahankan kondisi tubuh dalam latihan.

b. Memberikan makanan yang dapat menyediakan energi untuk aktifitas olahraga.

c. Menentukan makanan dan frekuensi makanan untuk latihan dan sesudah bertanding.

d. Menggunakan prinsip gizi dalam menurunkan dan menaikan berat badan.

Dengan demikian, atlet-atlet di Pusat Pendidikan dan Latihan Pelajar (PPLP) Ragunan terpenuhi asupan makanan yang dibutuhkan untuk atlet pada saat latihan dan pertandingan. Dalam hal latihan, para pelatih dan Pembina berperan penting untuk memajukan prestasi atlet atas nama Pusat Pendidikan dan Latihan Pelajar (PPLP) Ragunan. Semua hal yang menunjang untuk menunjang program latihan sangat diperhatikan di Pusat Pendidikan dan Latihan Pelajar (PPLP) Ragunan agar program latihan yang diberikan berjalan dengan baik. Begitu pun bila atlet terkena cedera, ada poliklinik khusus untuk merawat atlet yang terkena cedera yang penanganannya langsung oleh dokter ahli cedera olahraga. Didalam poliklinik PPLP Ragunan terdapat tim kesehatan yang terdiri dari, dokter ahli cedera olahraga, 3 perawat, dan 3 ahli sport massage.

Kerangka Berfikir. Cedera olahraga adalah kerusakan tiba-tiba yang terjadi pada tubuh pada saat melakukan aktifitas olahraga. Jadi cedera olahraga dapat terjadi kapan saja dan pada bagian tubuh mana saja.

Taekwondo berasal dari bahasa korea yang terdiri dari tiga suku kata yaitu tae artinya kaki/ menghancurkan dengan teknik menendang, kwon artinya tangan/ menghantam dan mempertahankan diri dengan teknik tangan, dan do artinya seni/cara mendisiplinkan diri. Jadi, taekwondo adalah olahraga beladiri yang menggunakan kaki dan tangan untuk menendang dan memukul lawan tanpa ada gerakan membanting ataupun mengunci. Serangan pada olahraga taekwondo banyak menggunakan kaki, sedangkan tangan lebih banyak digunakan untuk gerakan menangkis serangan.

Olahraga beladiri taekwondo sangat rentan terkena cedera, karena olahraga ini merupakan olahraga full body contact. Kemungkinan banyaknya cedera yang terjadi pada olahraga beladiri taekwondo adalah pada tubuh bagian bawah, antara lain, tungkai, lutut, dan telapak kaki. Jenis cedera pada olahraga beladiri taekwondo sama besarnya, yaitu cedera kulit, otot, tendo, ligament, dan tulang. Dilihat dari cara bertarung, kemungkinan cedera yang terjadi bersifat akut. Cedera olahraga akan banyak terjadi pada saat latihan karena latihan memerlukan banyak waktu dibanding saat bertanding. penyebab banyaknya cedera olahraga full body contact adalah faktor eksternal violence.

Judo berasal dari bahasa jepang kuno yang terdiri dari dua suku kata yaitu, $j u$ yang berarti lembut, dan do yang berarti seni. Jadi, judo adalah cara yang lembut. Maksud lembut disini bukanlah lemah lembut, maksud lembut disini adalah membanting lawan dengan cara menggoyahkan terlebih dahulu keseimbangan lawan dengan cara menarik atau mendorong lalu membanting lawan tanpa melepaskan tumpuan genggaman lawan.

Kemungkinan banyaknya cedera pada olahraga beladiri judo sangat besar, karena cedera olahraga bias terjadi kapan saja. Bagian tubuh yang sering terkena cedera 
olahraga pada olahraga beladiri judo kemungkinan pada tubuh bagian atas, diantaranya adalah, punggung, pundak, dan tangan. Jenis cedera yang terjadi akan sangat banyak, tetapi kemungkinan yang paling banyak pada bagian sendi. Cedera pada olahraga beladiri judo banyak bersifat akut. Cedera olahraga akan banyak terjadi pada saat latihan. Penyebab cedera pada olahraga beladiri judo adalah karena faktor eksternal violence.

Dilihat dari cara bertarung yang berbeda antara olahraga beladiri taekwondo dan olahraga beladiri judo, kemungkinan cederanya juga pasti berbeda. Taekwondo kemungkinan banyak mengalami cedera pada tubuh bagian bawah, sedangkan judo akan banyak mengalami cedera pada tubuh bagian atas. Untuk jenis cedera olahraga pada kedua olahraga beladiri tersebut sama besar, karena cedera terjadi secara tiba-tiba. Kedua olahraga beladiri memiliki kemungkinan cedera yang bersifat akut karena kedua olahraga beladiri tersebut merupakan olahraga full body contact. Semua olahraga, termasuk olahraga beladiri diatas akan banyak mengalami cedera pada saat latihan. Penyebabnya pun sama, yaieu karena faktor eksternal violence.

\section{METODE}

Penelitian ini bertujuan untuk mengetahui perbandingan cedera olahraga pada atlet taekwondo dan judo selama berada di Pusat Pendidikan dan Latihan Pelajar (PPLP) Ragunan. Meliputi prosentasi atlet yang cedera, lokasi yang sering cedera, penyebab cedera, sifat cedera, jenis cedera, penanganan cedera, dan hasil yang ada dapat dilakukan perbandingan perbedaan cedera antara atlet taekwondo dan judo selama berada di PPLP Ragunan.

Instrument Penelitian. 1. Untuk pengumpulan data yang akan diolah dari analisis, digunakan instrument penelitian dengan menggunakan teknik wawancara dan pemeriksaan langsung.

2. Kamera digital.

3. Alat tulis.
4. Kuisioner.

Teknik Pengumpulan Data. Teknik pengumpulan data untuk penelititan ini dengan cara sebagai berikut:

\section{Wawancara}

Teknik wawancara yaitu mendapatkan informasi dengan cara bertanya langsung kepada atlet dan tim kesehatan poliklinik PPLP Ragunan (dokter) instrument penelitian dalam pengumpulan data. Adapun untuk pembuatan kisi-kisi dan spesifikasi data penelitian membuat komponen yang lebih khusus mengarah kepada ruang lingkup mengenai cedera olahraga terhadap atlet taekwondo dan atlet judo selama berada Pusat Pendidikan dan Latihan Pelajar (PPLP) Ragunan adalah sebagai berikut:

\begin{tabular}{|c|c|c|c|}
\hline No. & Dimensi & Aspek & Indikator \\
\hline 1. & $\begin{array}{l}\text { Pernah } \\
\text { mengalami } \\
\text { cedera olahraga }\end{array}$ & $\begin{array}{l}\square \text { Selama } \\
\text { berada di PPLP } \\
\text { Ragunan }\end{array}$ & $\begin{array}{ll}> & \text { Ya } \\
> & \text { Tidak }\end{array}$ \\
\hline 2. & $\begin{array}{l}\text { Bagian tubuh } \\
\text { yang terkena } \\
\text { cedera olahraga }\end{array}$ & Bagian tubuh atas & $\begin{array}{ll}> & \text { Kepala } \\
> & \text { Leher } \\
> & \text { Badan } \\
> & \text { Punggung } \\
> & \text { Lengan } \\
\text { Tangan dan } & \\
\text { Pergelangan } \\
\text { Tangan } \\
> & \text { Jari } \\
> & \text { Pinggang } \\
> & \text { Lutut } \\
> & \text { Paha } \\
\text { Kaki/ } & \text { Tungkai } \\
\text { Bawah } \\
> & \text { Tumit } \\
> & \text { Telapak } \\
& \text { Kaki } \\
\end{array}$ \\
\hline 3. & $\begin{array}{l}\text { Jenis-jenis } \\
\text { Cedera }\end{array}$ & $\begin{array}{ll}> & \text { Kulit } \\
& \\
& \text { Otot dan } \\
& \text { Tendo } \\
> & \text { Ligamen } \\
> & \text { Sendi } \\
& \text { Tulang }\end{array}$ & 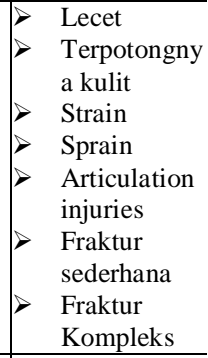 \\
\hline 4. & $\begin{array}{l}\text { Waktu } \\
\text { terjadinya atau } \\
\text { sifat cedera } \\
\text { olahraga } \\
\end{array}$ & $>$ Cedera Akut & $\begin{array}{l}\text { Hanya sekali } \\
\text { terkena } \\
\text { cedera }\end{array}$ \\
\hline 5. & $\begin{array}{l}\text { Kapan Saat } \\
\text { Terjadinya } \\
\text { Cedera }\end{array}$ & $\begin{array}{l}\text { Pada saat } \\
\text { berolahraga }\end{array}$ & $\begin{array}{l}\text { Saat } \\
\text { latihan } \\
>\begin{array}{l}\text { Saat } \\
\text { bertanding }\end{array} \\
\end{array}$ \\
\hline 6. & $\begin{array}{l}\text { Cedera Olahraga } \\
\text { berdasarkan } \\
\text { sebab-sebab } \\
\text { cederanya }\end{array}$ & $\begin{array}{l}\text { Eksternal } \\
\text { Violence } \\
\\
\text { Internal } \\
\text { Violence } \\
\\
\text { Over use }\end{array}$ & $\begin{array}{l}\text { Sebab } \\
\text { cedera } \\
\text { berasal dari } \\
\text { luar tubuh. } \\
\text { Sebab } \\
\text { cedera } \\
\text { berasal dari }\end{array}$ \\
\hline
\end{tabular}




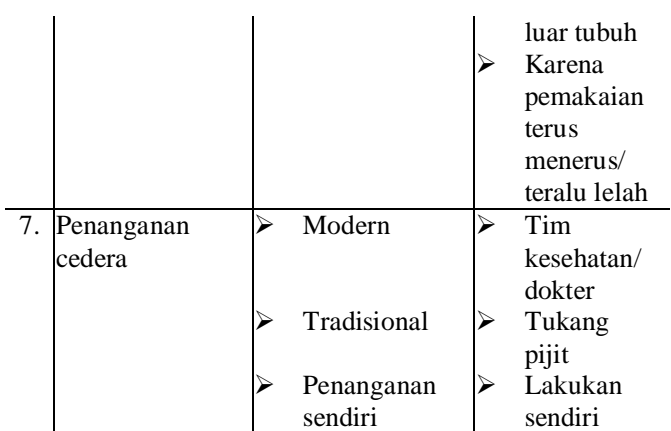

\section{Pemeriksaan}

Pemeriksaan langsung terhadap atlet yang sedang mengalami cedera dalam pemeriksaan jenis cederanya.

\section{HASIL DAN PEMBAHASAN}

\section{Hasil penelitian pada atlet taekwondo}

Berdasarkan wawancara yang dilakukan pada atlet taekwondo PPLP Ragunan, diperoleh data cedera olahraga sebagai berikut. Untuk lebih jelasnya dapat dilihat dalam tabel dibawah.

Tabel 1. Data A tlet Taekwondo Berdasarkan Pernah Mengalami Cedera Olahraga

\begin{tabular}{c|c|c|c|c} 
No. & Kategori & Jumlah atlet & $\begin{array}{c}\text { Jumlah } \\
\text { atlet cedera }\end{array}$ & $\begin{array}{c}\text { Prosentase } \\
(\boldsymbol{\%})\end{array}$ \\
\hline 1. & Ya & 23 & 22 & $95.65 \%$ \\
\hline 2. & Tidak & 23 & 1 & $4.35 \%$
\end{tabular}

Sumber : Hasil wawancara atlet taekwondo

Berdasarkan tabel diatas, dapat dilihat bahwa 22 atlet $95.65 \%$ taekwondo pernah mengalami cedera olahraga, sedangkan 1 atlet $4.35 \%$ tidak pernah mengalami cedera olahraga. Dengan demikian dapat disimpulkan bahwa olahraga beladiri taekwondo sangat rentan terkena cedera olahraga.

Tabel 2. Data atlet taekwondo berdasarkan jumlah kasus cedera yang dialami.

\begin{tabular}{c|c|c|c|c} 
No. & $\begin{array}{c}\text { Jumlah } \\
\text { atlet }\end{array}$ & $\begin{array}{c}\text { Jumlah cedera } \\
\text { yang } \\
\text { dialami/atlet }\end{array}$ & $\begin{array}{c}\text { Jumlah } \\
\text { kasus } \\
\text { cedera }\end{array}$ & $\begin{array}{c}\text { Prosentase } \\
(\%)\end{array}$ \\
\hline 1. & 2 atlet & 3 kali & 6 kasus & $6.52 \%$ \\
\hline 2. & 14 atlet & 4 kali & 56 kasus & $60.87 \%$ \\
\hline 3. & 6 atlet & 5 kali & 30 kasus & $32.61 \%$
\end{tabular}

\begin{tabular}{c|c|c|c} 
Jml | 22 atlet $\mid 92$ kasus | & - & $100 \%$ \\
Sumber : Hasil wawancara atlet taekwondo
\end{tabular}

Berdasarkan tabel diatas, dapat dilihat bahwa 2 atlet mengalami 3 kali cedera olahraga atau 6 kasus (6.52\%), 14 atlet mengalami 4 kali cedera olahraga atau 56 kasus (60.87\%), dan 6 atlet mengalami 5 kali cedera olahraga 30 kasus (32.61\%). Jadi, atlet taekwondo mengalami cedera minimal 3 kali cedera, maksimal mengalami 5 kali cedera dan yang paling banyak mengalami 4 kali cedera.

Tabel 3. Data Jumlah Kasus Cedera Atlet Taekwondo Berdasarkan Bagian Tubuh yang Terkena Cedera

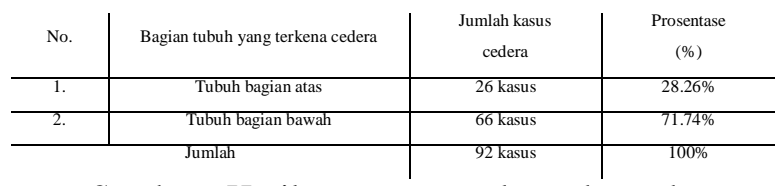

Sumber : Hasil wawancara atlet taekwondo

Berdasarkan tabel diatas, dapat dilihat bahwa bagian tubuh yang terkena cedera pada atlet taekwondo adalah 26 kasus cedera (28.26\%) pada tubuh bagian atas, dan 66 kasus cedera $(71.74 \%)$ pada tubuh bagian bawah. Jadi, olahraga taekwondo sangat rentan terkena cedera pada tubuh bagian bawah.

Tabel 4. Data Jumlah Kasus Cedera Atlet Taekwondo Berdasarkan pada Saat Terjadi Cedera

\begin{tabular}{c|c|c|c} 
No. & Pada saat terjadi cedera & $\begin{array}{c}\text { Jumlah kasus } \\
\text { cedera }\end{array}$ & $\begin{array}{c}\text { Prosentase } \\
(\%)\end{array}$ \\
\hline 1. & Pada saat latihan & 80 kasus & $86.96 \%$ \\
\hline 2. & Pada saat bertanding & 12 kasus & $13.04 \%$ \\
\hline \multicolumn{2}{r|}{ Jumlah } & 92 kasus & $100 \%$
\end{tabular}

Sumber: Hasil wawancara atlet taekwondo

Berdasarkan tabel diatas, dapat dilihat bahwa cedera olahraga yang terjadi pada saat latihan ada 80 kasus (86.96\%), sedangkan cedera olahraga yang terjadi pada saat berlatih ada 12 kasus (13.04\%). Jadi, cedera olahraga yang banyak dialami atlet taekwondo terjadi pada saat latihan.

Tabel 5. Data Jumlah Kasus Cedera A tlet Taekwondo Berdasarkan Sebabsebab Terjadi Cedera 


\begin{tabular}{c|c|c|c} 
No. & $\begin{array}{c}\text { Sebab-sebab terjadi } \\
\text { cedera }\end{array}$ & $\begin{array}{c}\text { Jumlah kasus } \\
\text { cedera }\end{array}$ & $\begin{array}{c}\text { Prosentase } \\
(\%)\end{array}$ \\
\hline 1. & Eksternal violence & 28 kasus & $30.43 \%$ \\
\hline 2. & Internal violence & 62 kasus & $67.40 \%$ \\
\hline 3. & Over-use & 2 kasus & $2.17 \%$ \\
\hline & Jumlah & 92 kasus & $100 \%$
\end{tabular}

Sumber : Hasil wawancara atlet taekwondo

Berdasarkan tabel diatas, dapat dilihat bahwa sebab cedera karena faktor eksternal violence ada 28 kasus (30.43\%), faktor internal violence ada 62 kasus $(67.40 \%)$, dan over-use ada 2 kasus (2.17\%). Jadi, cedera olahraga yang banyak dialami atlet taekwondo terjadi karena faktor internal violence.

Tabel 6. Data Jumlah Kasus Cedera Atlet Taekwondo Berdasarkan Penanganan Cedera yang Dilakukan

\begin{tabular}{c|c|c|c} 
No. & $\begin{array}{c}\text { Penanganan cedera } \\
\text { yang dilakukan }\end{array}$ & $\begin{array}{c}\text { Jumlah kasus } \\
\text { cedera }\end{array}$ & $\begin{array}{c}\text { Prosentase } \\
(\%)\end{array}$ \\
\hline 1. & $\begin{array}{c}\text { Di poliklinik PPLP } \\
\text { Ragunan }\end{array}$ & 80 kasus & $86.96 \%$ \\
\hline 2. & $\begin{array}{c}\text { Bukan di poliklinik } \\
\text { PPLP Ragunan }\end{array}$ & 12 kasus & $13.04 \%$ \\
\hline \multicolumn{2}{c}{ Jumlah } & 92 kasus & $100 \%$
\end{tabular}

Sumber : Hasil wawancara atlet taekwondo

Berdasarkan tabel diatas, dapat dilihat bahwa penanganan cedera olahraga yang dibawa ke poliklinik PPLP Ragunan ada 80 kasus (86.96\%), sedangkan 12 kasus (13.04\%) tidak dibawa ke poliklinik PPLP Ragunan. Jadi, penanganan cedera olahraga yang banyak dilakukan atlet taekwondo adalah di bawa ke poliklinik PPLP Ragunan.

2. Hasil penelitian pada dokter yang menangani cedera olahraga atlet taekwondo.

Berdasarkan wawancara yang dilakukan pada dokter yang menangani cedera olahraga para atlet taekwondo yang penanganannya dibawa ke poliklinik PPLP Ragunan yaitu sebanyak 80 kasus cedera. Untuk lebih jelasnya dapat dilihat pada tabel dibawah.

Tabel 7. Data Dokter yang $M$ enangani Jumlah $K$ asus $C$ edera Atlet Taekwondo, Berdasarkan Jenis Cedera Olahraga

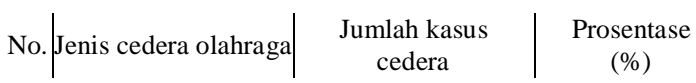

\begin{tabular}{c|c|c|c}
1. & Kulit & 4 kasus & $5 \%$ \\
\hline 2. & Otot \& Tendo & 36 kasus & $45 \%$ \\
\hline 3. & Ligament & 30 kasus & $37.5 \%$ \\
\hline 4. & Sendi & 8 kasus & $10 \%$ \\
\hline 5. & Tulang & 2 kasus & $2.5 \%$ \\
\hline & Jumlah & 80 kasus & $100 \%$
\end{tabular}

Sumber: Hasil wawancara dokter PPLP Ragunan

Berdasarkan tabel diatas, dapat dilihat bahwa jenis cedera pada atlet taekwondo terdiri dari 4 kasus (5\%) cedera kulit, 36 kasus $(45 \%)$ cedera otot $\&$ tendo, 30 kasus (37.5\%) cedera ligament, 8 kasus (10\%) cedera sendi, dan 2 kasus $(2.5 \%)$ cedera tulang. Jadi, kebanyakan jenis cedera olahraga yang terjadi pada atlet taekwondo PPLP Ragunan adalah jenis cedera otot $\&$ tendo. Sesuai data dari dokter di poliklinik PPLP Ragunan.

Tabel 8. Data D okter yang $M$ enangani Jumlah $\mathrm{K}$ asus $\mathrm{C}$ edera A tlet Taekwondo, Berdasarkan Berat Ringannya Cedera Olahraga

\begin{tabular}{c|c|c|c} 
No. & $\begin{array}{c}\text { Berat ringannya } \\
\text { cedera olahraga }\end{array}$ & $\begin{array}{c}\text { Jumlah kasus } \\
\text { cedera }\end{array}$ & $\begin{array}{c}\text { Prosentase } \\
(\%)\end{array}$ \\
\hline 1. & Cedera berat & 22 kasus & $27.5 \%$ \\
\hline 2. & Cedera ringan & 58 kasus & $72.5 \%$ \\
\hline \multicolumn{2}{r|}{ Jumlah } & 80 kasus & $100 \%$
\end{tabular}

Sumber: Hasil wawancara dokter PPLP Ragunan

Berdasarkan tabel diatas, dapat dilihat bahwa cedera olahraga yang dialami atlet taekwondo ada 22 kasus (27.5\%) mengalami cedera berat, dan 58 kasus $(72 . \% \%)$ mengalami cedera ringan. Jadi, kebanyakan cedera yang dialami oleh atlet taekwondo adalah cedera ringan. Sesuai data dari dokter di poliklinik PPLP Ragunan.

\section{Tabel 9. Data D okter yang Menangani J umlah Kasus C edera A tlet}

Taekwondo, Berdasarkan Waktu Terjadi/ Sifat Cedera Olahraga

\begin{tabular}{c|c|c|c} 
No. & $\begin{array}{c}\text { Waktu terjadi/ sifat } \\
\text { cedera olahraga }\end{array}$ & $\begin{array}{c}\text { Jumlah kasus } \\
\text { cedera }\end{array}$ & $\begin{array}{c}\text { Prosentase } \\
(\%)\end{array}$ \\
\hline 1. & Cedera akut & 34 kasus & $42.5 \%$ \\
\hline 2. & Cedera kronis & 46 kasus & $57.5 \%$ \\
\hline \multicolumn{2}{r|}{ Jumlah } & 80 kasus & $100 \%$
\end{tabular}

Sumber : Hasil wawancara dokter PPLP Ragunan

Berdasarkan tabel diatas, dapat dilihat bahwa cedera olahraga yang dialami oleh atlet taekwondo berdasarkan waktu/sifatnya 
ada 34 kasus (42.5\%) cedera akut, dan 46 kasus $(57.5 \%)$ cedera kronis. Jadi, kebanyakan cedera yang dialami oleh atlet taekwondo adalah cedera kronis. Sesuai data dari dokter di poliklinik PPLP Ragunan.

\section{Hasil penelitian pada atlet judo}

Berdasarkan wawancara yang dilakukan pada atlet judo PPLP Ragunan, diperoleh data cedera olahraga sebagai berikut. Untuk lebih jelasnya dapat dilihat dalam tabel dibawah.

Tabel 10. Data Atlet Judo Berdasarkan $\mathbf{P}$ ernah Mengalami Cedera Olahraga

\begin{tabular}{c|c|c|c|c}
$\begin{array}{c}\text { No } \\
\dot{y}\end{array}$ & Kategori & $\begin{array}{c}\text { Jumlah } \\
\text { atlet }\end{array}$ & $\begin{array}{c}\text { Jumlah } \\
\text { atlet cedera }\end{array}$ & Prosentase (\%) \\
\hline 1. & Ya & 18 & 18 & $100 \%$ \\
\hline 2. & Tidak & 18 & 0 & $0 \%$
\end{tabular}

Sumber : Hasil Wawancara Atlet Judo

Berdasarkan tabel diatas, dapat dilihat bahwa semua atlet judo yaitu 18 atlet (100\%) pernah mengalami cedera olahraga. Dengan demikian dapat disimpulkan bahwa olahraga beladiri judo sangat rentan terkena cedera olahraga.

Tabel 11. Data Atlet Judo Berdasarkan Jumlah Kasus Cedera Olahraga yang Dialami

\begin{tabular}{|c|c|c|c|c|}
\hline No. & $\begin{array}{c}\text { Jumlah } \\
\text { atlet }\end{array}$ & $\begin{array}{c}\text { Jumlah cedera } \\
\text { yang dialami/ } \\
\text { atlet }\end{array}$ & $\begin{array}{l}\text { Jumlah kasus } \\
\text { cedera }\end{array}$ & $\begin{array}{c}\text { Prosentase } \\
\text { kasus (\%) }\end{array}$ \\
\hline 1. & 2 atlet & 2 kali & 4 kasus & $6.67 \%$ \\
\hline 2. & 9 atlet & 3 kali & 27 kasus & $45 \%$ \\
\hline 3. & 6 atlet & 4 kali & 24 kasus & $40 \%$ \\
\hline 4. & 1 atlet & 5 kali & 5 kasus & $8.33 \%$ \\
\hline Jml & 18 atlet & - & 60 kasus & $100 \%$ \\
\hline
\end{tabular}

Berdasarkan tabel diatas, dapat dilihat bahwa 2 atlet mengalami 2 kali cedera atau 4 kasus (6.67\%), 9 atlet mengalami 3 kali cedera atau 27 kasus (45\%), 6 atlet mengalami 4 kali cedera atau 24 kasus (40\%), dan 1 atlet mengalami 5 kali cedera atau 5 kasus (8.33\%). Jadi, atlet judo mengalami cedera olahraga minimal 2 kali cedera, maksimal 5 kali cedera dan yang paling banyak terjadi 3 kali cedera.

Tabel 12. Data Jumlah Kasus Cedera Atlet Judo Berdasarkan Bagian Tubuh yang Terkena Cedera Olahraga

\begin{tabular}{c|c|c|c} 
No. & $\begin{array}{c}\text { Bagian tubuh yang } \\
\text { terkena cedera } \\
\text { olahraga }\end{array}$ & $\begin{array}{c}\text { Jumlah kasus } \\
\text { cedera }\end{array}$ & $\begin{array}{c}\text { Prosentase } \\
(\%)\end{array}$ \\
\hline 1. & Tubuh bagian atas & 40 kasus & $66.67 \%$ \\
\hline 2. & Tubuh bagian bawah & 20 kasus & $33.33 \%$ \\
\hline & Jumlah & 60 kasus & $100 \%$
\end{tabular}

Sumber : Hasil wawancara atlet judo

Berdasarkan tabel diatas, dapat dilihat bahwa bagian tubuh yang terkena cedera pada atlet judo adalah 40 kasus cedera (66.67\%) pada tubuh bagian atas, dan 20 kasus cedera $(33.33 \%)$ pada tubuh bagian bawah. Jadi, olahraga judo sangat rentan terkena cedera pada tubuh bagian atas.

Tabel 13. Data Jumlah Kasus Cedera

Atlet J udo B erdasarkan pada $S$ aat Terjadi Cedera Olahraga

\begin{tabular}{c|c|c|c} 
No. & $\begin{array}{c}\text { Pada saat terjadi } \\
\text { cedera olahraga }\end{array}$ & $\begin{array}{c}\text { Jumlah kasus } \\
\text { cedera }\end{array}$ & $\begin{array}{c}\text { Prosentase } \\
(\%)\end{array}$ \\
\hline 1. & Pada saat latihan & 48 kasus & $80 \%$ \\
\hline 2. & Pada saat bertanding & 12 kasus & $20 \%$ \\
\hline & Jumlah & 60 kasus & $100 \%$
\end{tabular}

Sumber : Hasil wawancara atlet judo

Berdasarkan tabel diatas, dapat dilihat bahwa cedera olahraga yang terjadi pada saat latihan ada 48 kasus (80\%), sedangkan cedera olahraga yang terjadi pada saat berlatih ada 12 kasus (20\%). Jadi, kebanyakan cedera olahraga yang ada pada atlet judo terjadi pada saat latihan.

\section{Tabel 14. Data Jumlah Kasus Cedera Atlet Judo Berdasarkan Sebab-sebab Terjadi Cedera Olahraga}

\begin{tabular}{c|c|c|c} 
No. & $\begin{array}{c}\text { Sebab-sebab terjadi } \\
\text { cedera olahraga }\end{array}$ & $\begin{array}{c}\text { Jumlah kasus } \\
\text { cedera }\end{array}$ & $\begin{array}{c}\text { Prosentase } \\
(\%)\end{array}$ \\
\hline 1. & Eksternal violence & 28 kasus & $46.67 \%$ \\
\hline 2. & Internal violence & 30 kasus & $50 \%$ \\
\hline 3. & Over-use & 2 kasus & $3.33 \%$ \\
\hline \multicolumn{2}{r|}{ Jumlah } & 60 kasus & $100 \%$
\end{tabular}

Sumber : Hasil wawancara atlet judo

Berdasarkan tabel diatas, dapat dilihat bahwa sebab cedera karena faktor eksternal violence ada 28 kasus (46.67\%), faktor internal violence ada 30 kasus (50\%), dan over-use ada 2 kasus (3.33\%). Jadi, penyebab terjadinya cedera olahraga pada atlet judo terjadi karena faktor internal violence. 
Tabel 15. Data Jumlah Kasus Cedera Atlet Judo Berdasarkan Penanganan Cedera Olahraga yang Dilakukan

\begin{tabular}{c|c|c|c} 
No. & $\begin{array}{c}\text { Penanganan cedera } \\
\text { olahraga yang } \\
\text { dilakukan }\end{array}$ & $\begin{array}{c}\text { Jumlah kasus } \\
\text { cedera }\end{array}$ & $\begin{array}{c}\text { Prosentase } \\
(\%)\end{array}$ \\
\hline 1. & $\begin{array}{c}\text { Di poliklinik PPLP } \\
\text { Ragunan }\end{array}$ & 50 kasus & $83.33 \%$ \\
\hline 2. & $\begin{array}{c}\text { Bukan di } \\
\text { poliklinik PPLP } \\
\text { Ragunan }\end{array}$ & 10 kasus & $16.67 \%$ \\
\hline & Jumlah & 60 kasus & $100 \%$
\end{tabular}

Sumber : Hasil wawancara atlet judo

Berdasarkan tabel diatas, dapat dilihat bahwa penanganan cedera olahraga yang dibawa ke poliklinik PPLP Ragunan ada 50 kasus (83.33\%), sedangkan 10 kasus (16.67\%) tidak dibawa ke poliklinik PPLP Ragunan. Jadi, kebanyakan cedera olahraga yang terjadi pada atlet judo di bawa ke poliklinik PPLP Ragunan.

\section{Hasil penelitian pada dokter yang} menangani cedera olahraga atlet judo

Berdasarkan wawancara yang dilakukan pada dokter yang menangani cedera olahraga para atlet judo yang penanganannya dibawa ke poliklinik PPLP Ragunan yaitu sebanyak 50 kasus cedera. Untuk lebih jelasnya dapat dilihat pada tabel dibawah.

\section{Tabel 16. Data Dokter yang Menangani Jumlah Kasus Cedera Atlet Judo, Berdasarkan Jenis Cedera Olahraga}

\begin{tabular}{c|c|c|c} 
No. & $\begin{array}{c}\text { Jenis cedera } \\
\text { olahraga }\end{array}$ & $\begin{array}{c}\text { Jumlah } \\
\text { kasus }\end{array}$ & $\begin{array}{c}\text { Prosentase } \\
(\%)\end{array}$ \\
\hline 1. & Kulit & 2 kasus & $4 \%$ \\
\hline 2. & Otot \& Tendo & 6 kasus & $12 \%$ \\
\hline 3. & Ligament & 20 kasus & $40 \%$ \\
\hline 4. & Sendi & 20 kasus & $40 \%$ \\
\hline 5. & Tulang & 2 kasus & $4 \%$ \\
\hline \multicolumn{2}{r}{ Jumlah } & 50 kasus & $100 \%$
\end{tabular}

Sumber : Hasil wawancara dokter PPLP Ragunan

Berdasarkan tabel diatas, dapat dilihat bahwa jenis cedera pada atlet judo terdiri dari 2 kasus (4\%) cedera kulit, 6 kasus $(12 \%)$ cedera otot \& tendo, 20 kasus $(40 \%)$ cedera ligament, 20 kasus (40\%) cedera sendi, dan 2 kasus (4\%) cedera tulang. Jadi, kebanyakan jenis cedera olahraga yang terjadi pada atlet judo PPLP Ragunan adalah jenis cedera ligament dan sendi. Sesuai data dari dokter di poliklinik PPLP Ragunan.

\section{Tabel 17. Data Dokter yang Menangani Jumlah Kasus Cedera Atlet Judo, Berdasarkan Berat Ringannya Cedera Olahraga}

\begin{tabular}{c|c|c|c} 
No. & $\begin{array}{c}\text { Berat ringannya } \\
\text { cedera olahraga }\end{array}$ & $\begin{array}{c}\text { Jumlah } \\
\text { kasus }\end{array}$ & $\begin{array}{c}\text { Prosentase } \\
(\%)\end{array}$ \\
\hline 1. & Cedera berat & 20 kasus & $40 \%$ \\
\hline 2. & Cedera ringan & 30 kasus & $60 \%$ \\
\hline & Jumlah & 50 kasus & $100 \%$
\end{tabular}

Sumber : Hasil Wawancara Dokter PPLP Ragunan

Berdasarkan tabel diatas, dapat dilihat bahwa cedera olahraga yang dialami atlet judo ada 20 kasus (40\%) mengalami cedera berat, dan 30 kasus $(60 \%)$ mengalami cedera ringan. Jadi, kebanyakan cedera yang dialami oleh atlet judo adalah cedera ringan. Sesuai data dari dokter di poliklinik PPLP Ragunan.

\section{Tabel 18. Data Dokter yang Menangani Jumlah Kasus Cedera Atlet Judo, Berdasarkan Waktu Terjadi/ Sifat Cedera Olahraga}

\begin{tabular}{c|c|c|c} 
No. & $\begin{array}{c}\text { Waktu terjadi/ sifat } \\
\text { cedera olahraga }\end{array}$ & $\begin{array}{c}\text { Jumlah } \\
\text { kasus } \\
\text { cedera }\end{array}$ & $\begin{array}{c}\text { Prosentase } \\
(\%)\end{array}$ \\
\hline 1. & Cedera akut & 21 kasus & $42 \%$ \\
\hline 2. & Cedera kronis & 29 kasus & $58 \%$ \\
\hline \multicolumn{2}{r|}{ Jumlah } & 50 kasus & $100 \%$
\end{tabular}

Sumber : Hasil wawancara dokter PPLP Ragunan

Berdasarkan tabel diatas, dapat dilihat bahwa cedera olahraga yang dialami oleh atlet judo berdasarkan waktu/sifatnya ada 21 kasus (42\%) cedera akut, dan 29 kasus (58\%) cedera kronis. Jadi, kebanyakan cedera yang dialami oleh atlet judo adalah cedera kronis. Sesuai data dari dokter di poliklinik PPLP Ragunan. 
5. Hasil perbandingan cedera olahraga antara atlet taekwondo dan atlet judo

Berdasarkan data yang didapat dari wawancara terhadap atlet taekwondo, atlet judo, dan dokter poliklinik PPLP Ragunan didapat hasil perbandingan cedera olahraga antara atlet taekwondo dan atlet judo. Untuk lebih jelasnya dapat dilihat pada tabel dibawah.

Tabel 19. Perbandingan Cedera O lahraga Antara Atlet Taekwondo Dan Atlet Judo Berdasarkan Pernah Mengalami Cedera Olahraga.

\begin{tabular}{c|c|c|c} 
No. & $\begin{array}{c}\text { Berdasarkan pernah } \\
\text { mengalami cedera } \\
\text { olahraga }\end{array}$ & Atlet taekwondo & Atlet judo \\
\hline 1. & Ya & $95.65 \%$ & $100 \%$ \\
\hline 2. & Tidak & $4.35 \%$ & $0 \%$
\end{tabular}

Sumber : Hasil Perbandingan Cedera Olahraga

Berdasarkan tabel diatas, dapat dilihat bahwa sebanyak $95.65 \%$ atlet taekwondo pernah mengalami cedera olahraga, sedangkan $4.35 \%$ tidak mengalami cedera olahraga. Dan pada atlet judo yang terkena cedera olahraga sebanyak $100 \%$. Jadi, dapat disimpulkan bahwa olahraga beladiri taekwondo dan olahraga beladiri judo sangat rentan terkena cedera olahraga.

Tabel 20. Perbandingan Cedera Olahraga Antara Atlet Taekwondo dan Atlet Judo Berdasarkan Jumlah Kasus Cedera Olahraga

\begin{tabular}{c|c|c|c}
\multirow{2}{*}{ No. } & \multirow{2}{*}{$\begin{array}{c}\text { Jumlah cedera yang } \\
\text { dialami/atlet }\end{array}$} & \multicolumn{2}{|c}{ Jumlah kasus } \\
\cline { 3 - 4 } & $2 \mathrm{kali}$ & Atlet taekwondo & Atlet judo \\
\hline 1. & $3 \mathrm{kali}$ & 6 kasus & 4 kasus \\
\hline 2. & $4 \mathrm{kali}$ & 56 kasus & 27 kasus \\
\hline 3. & $5 \mathrm{kali}$ & 30 kasus & 24 kasus \\
\hline 4. & Jumlah & 92 kasus & 60 kasus
\end{tabular}

Sumber : Hasil Perbandingan Cedera Olahraga

Berdasarkan tabel diatas, dapat dilihat bahwa cedera olahraga yang terjadi pada atlet taekwondo di temukan 92 kasus, sedangkan pada atlet judo ditemukan 60 kasus cedera olahraga.
Tabel 21. Perbandingan Cedera Olahraga Antara Atlet Taekwondo dan Atlet Judo Berdasarkan Bagian Tubuh yang Terkena Cedera Olahraga

\begin{tabular}{c|c|c|c} 
No. & $\begin{array}{c}\text { Bagian tubuh yang } \\
\text { terkena cedera } \\
\text { olahraga }\end{array}$ & $\begin{array}{c}\text { Atlet } \\
\text { taekwondo }\end{array}$ & Atlet judo \\
\hline 1. & Bagian tubuh atas & $28.26 \%$ & $66.67 \%$ \\
\hline 2. & Bagian tubuh bawah & $71.74 \%$ & $33.33 \%$
\end{tabular}

Sumber : Hasil Pernbandingan Cedera Olahraga

Berdasarkan tabel diatas, dapat dilihat bahwa bagian tubuh yang terkena cedera olahraga antara atlet taekwondo dan atlet judo berbeda, dimana atlet taekwondo lebih banyak mengalami cedera olahraga pada tubuh bagian bawah yaitu $71.74 \%$. Sedangkan pada atlet judo, bagian tubuh yang banyak terjadi cedera olahraga adalah pada bagian tubuh atas, yaitu $66.67 \%$.

Tabel 22. Perbandingan $\mathrm{C}$ edera Olahraga Antara Atlet Taekwondo dan Atlet Judo Berdasarkan Pada Saat Terjadi Cedera Olahraga.

\begin{tabular}{c|c|c|c} 
No. & $\begin{array}{c}\text { Saat terjadi cedera } \\
\text { olahraga }\end{array}$ & $\begin{array}{c}\text { Atlet } \\
\text { taekwondo }\end{array}$ & Atlet judo \\
\hline 1. & Pasa saat latihan & $86.96 \%$ & $80 \%$ \\
\hline 2. & Pada saat bertanding & $13.04 \%$ & $20 \%$
\end{tabular}

Sumber : Hasil perbandingan cedera olahraga

Berdasarkan tabel diatas, dapat ddilihat bahwa semua cedera yang terjadi pada atlet taekwondo dan atlet judo adalah ketika berlatih. Pada atlet taekwondo 86.96\%, sedangkan pada atlet judo $80 \%$.

Tabel 23. Perbandingan Cedera O lahraga Antara Atlet $\mathbf{T}$ aekwondo dan Atlet Judo Berdasarkan Sebab-sebab Terjadi Cedera Olahraga

\begin{tabular}{c|c|c|c} 
No. & $\begin{array}{c}\text { Sebab-sebab terjadi cedera } \\
\text { olahraga }\end{array}$ & Atlet taekwondo & Atlet judo \\
\hline 1. & Eksternal violence & $30.43 \%$ & $46.67 \%$ \\
\hline 2. & Internal violence & $67.40 \%$ & $50 \%$ \\
\hline 3. & Over-use & $2.17 \%$ & $3.33 \%$
\end{tabular}

Sumber : Hasil perbandingan cedera olahraga

Berdasarkan tabel diatas, dapat dilihat bahwa sebab-sebab terjadi olahraga yang 
paling banyak terjadi pada atlet taekwondo dan atlet judo adalah karena faktor internal violence. Pada atlet taekwondo ada $67.40 \%$, sedangkan pada atlet judo $50 \%$.

\section{Tabel 24. Perbandingan $C$ edera O lahraga A ntara Atlet Taekwondo dan Atlet Judo Berdasarkan Penanganan Cedera Olahraga yang Dilakukan}

\begin{tabular}{c|c|c|c} 
No. & $\begin{array}{c}\text { Penanganan cedera } \\
\text { olahraga yang dilakukan }\end{array}$ & $\begin{array}{c}\text { Atlet } \\
\text { taekwondo }\end{array}$ & Atlet judo \\
\hline 1. & $\begin{array}{c}\text { Di poliklinik PPLP } \\
\text { Ragunan }\end{array}$ & $86.96 \%$ & $83.33 \%$ \\
\hline 2. & $\begin{array}{c}\text { Bukan di poliklinik } \\
\text { PPLP Ragunan }\end{array}$ & $13.04 \%$ & $16.67 \%$
\end{tabular}

Sumber : Hasil Perbandingan Cedera Olahraga

Berdasarkan tabel diatas, dapat dilihat bahwa penanganan cedera olahraga yang terjadi di PPLP Ragunan kebanyakan dibawa ke poliklinik yang ada di tempat tersebut. Pada kasus cedera olahraga atlet taekwondo ada $86.96 \%$, sedangkan pada kasus cedera olahraga atlet judo ada $83.33 \%$.

Tabel 25. Perbandingan $C$ edera Olahraga Antara Atlet Taekwondo dan Atlet Judo Berdasarkan Jenis Cedera Olahraga

\begin{tabular}{c|c|c|c} 
No. & $\begin{array}{c}\text { Jenis cedera } \\
\text { olahraga }\end{array}$ & $\begin{array}{c}\text { Atlet } \\
\text { taekwondo }\end{array}$ & Atlet judo \\
\hline 1. & Kulit & $5 \%$ & $4 \%$ \\
\hline 2. & Otot \& Tendo & $45 \%$ & $12 \%$ \\
\hline 3. & Ligament & $37.5 \%$ & $40 \%$ \\
\hline 4. & Sendi & $10 \%$ & $40 \%$ \\
\hline 5. & Tulang & $2.5 \%$ & $4 \%$
\end{tabular}

Sumber : Hasil perbandingan cedera olahraga

Berdasarkan tabel diatas, dapat dilihat bahwa ada perbedaan jenis cedera yang dialami oleh atlet taekwondo dan atlet judo. Pada atlet taekwondo, cedera pada otot, tendo, dan ligament mempunyai prosentase terbesar. Sedangkan, pada atlet judo prosentase terbesar ada pada cedera ligament dan sendi.
Tabel 26. Perbandingan $C$ edera O lahraga Antara Atlet Taekwondo dan Atlet Judo Berdasarkan Berat Ringannya Cedera Olahraga

\begin{tabular}{c|c|c|c} 
No. & $\begin{array}{c}\text { Berat ringannya cedera } \\
\text { olahraga }\end{array}$ & $\begin{array}{c}\text { Atlet } \\
\text { taekwondo }\end{array}$ & Atlet judo \\
\hline 1. & Cedera berat & $27.5 \%$ & $40 \%$ \\
\hline 2. & Cedera ringan & $72.5 \%$ & $60 \%$
\end{tabular}

Sumber : Hasil perbandingan cedera olahraga

Berdasarkan tabel diatas, dapa dilihat bahwa berdasarkan berat ringannya cedera olahraga kedua atlet, baik atlet taekwondo maupun atlet judo banyak mengalami cedera ringan. Pada atlet taekwondo $72.5 \%$, sedangkan pada atlet judo $60 \%$.

Tabel 27. Perbandingan Cedera Olahraga Antara Atlet Taekwondo dan Atlet Judo Berdasarkan Waktu Terjadi/ Sifat Cedera Olahraga

\begin{tabular}{c|c|c|c} 
No. & $\begin{array}{c}\text { Waktu terjadi/ sifat } \\
\text { cedera olahraga }\end{array}$ & $\begin{array}{c}\text { Atlet } \\
\text { taekwondo }\end{array}$ & Atlet judo \\
\hline 1. & Cedera akut & $42.5 \%$ & $42 \%$ \\
\hline 2. & $\begin{array}{c}\text { Cedera kronis } \\
\text { Sumber : Hasil perbandingan cedera olahraga }\end{array}$
\end{tabular}

Berdasarkan tabel diatas, dapat dilihat bahwa cedera yang dialami oleh kedua atlet, baik atlet taekwondo maupun atlet judo banyak mengalami cedera kronis. Pada atlet taekwondo $57.5 \%$, sedangkan pada atlet judo $58 \%$.

\section{B. Analisis Data Penelitian}

Berdasarkan hasil penelitian tentang cedera olahraga pada atlet taekwondo, didapat atlet taekwondo yang terkena cedera ada 22 atlet $(95.65 \%)$ dan 1 atlet $(4.35 \%)$ tidak mengalami cedera olahraga. Dari 22 atlet taekwondo didapat 92 jumlah kasus cedera olahraga. Atlet taekwondo paling banyak mengalami cedera olahraga pada tubuh bagian bawah yaitu ada 66 kasus cedera $(71.74 \%)$. Atlet taekwondo paling banyak mengalami cedera olahraga pada saat latihan yaitu ada 80 kasus (86.96\%). Atlet taekwondo paling banyak mengalami cedera olahraga karena faktor internal 
violence yaitu ada 62 kasus (67.40\%). Atlet taekwondo paling banyak menangani cedera olahraga dengan pergi ke poliklinik PPLP Ragunan yaitu ada 80 kasus $(86.96 \%)$. Dari data yang ada di poliklinik PPLP Ragunan, didapat atlet taekwondo paling banyak mengalami cedera olahraga jenis otot \& tendo yaitu ada 36 kasus cedera (45\%). Atlet taekwondo paling banyak mengalami cedera ringan yaitu ada 58 kasus $(72.5 \%)$. Atlet taekwondo paling banyak mengalami cedera kronis yaitu ada 46 kasus $(57.5 \%)$.

Berdasarkan hasil penelitian tentang cedera olahraga pada atlet judo, didapat atlet judo yang terkena cedera ada 18 atlet $(100 \%)$ atau semua atlet judo mengalami cedera olahraga. Dari 18 atlet judo yang mengalami cedera olahraga didapat 60 kasus cedera olahraga. Atlet judo paling banyak mengalami cedera pada tubuh bagian atas yaitu ada 40 kasus cedera $(66.67 \%)$. Atlet judo paling banyak mengalami cedera olahraga pada saat latihan yaitu ada 48 kasus cedera (80\%). Atlet judo paling banyak mengalami cedera olahraga karena faktor internal violence yaitu ada 30 kasus cedera $(50 \%)$. Atlet judo paling banyak menangani cedera olahraga dengan pergi ke poliklinik PPLP Ragunan yaitu ada 50 kasus cedera $(83.33 \%)$. Atlet judo paling banyak mengalami cedera jenis sendi dan ligament yaitu masing- masing ada 20 kasus cedera (40\%). Atlet judo paling banyak mengalami cedera ringan yaitu ada 30 kasus cedera $(60 \%)$. Atlet judo paling banyak mengalami cedera kronis yaitu ada 29 kasus cedera $(58 \%)$.

Dari analisis penelitian kedua atlet diatas, yaitu antara atlet taekwondo dan atlet judo didapat kesamaan dan perbedaan. Atlet taekwondo tidak semuanya mengalami cedera olahraga tapi hanya $95.65 \%$, beda dengan atlet judo yang semua atletnya mengalami cedera olahraga $100 \%$. Pada atlet olahraga beladiri taekwondo ditemukan 92 kasus cedera olahraga dari 22 atlet yang mengalami cedera, sedangkan pada atlet olahraga beladiri judo ditemukan 60 kasus cedera olahraga dari 18 atlet. Berdasarkan bagian tubuh yang terkena cedera olahraga, pada atlet taekwondo banyak terjadi cedera olahraga pada tubuh bagian bawah, sedangkan pada atlet judo banyak terjadi cedera olahraga pada tubuh bagian atas.

Berdasarkan saat terjadinya cedera olahraga, pada atlet taekwondo dan atlet judo paling banyak terjadi cedera olahraga pada saat latihan. Berdasarkan sebab-sebab terjadinya cedera olahraga, atlet taekwondo dan atlet judo sama-sama banyak mengalami cedera olahraga karena faktor internal violence. Berdasarkan penanganan cedera olahraga yang dilakukan, atlet taekwondo dan atlet judo lebih banyak memilih pergi ke tempat yang disediakan yaitu poliklinik PPLP Ragunan. Berdasarkan jenis cedera olahraga yang dialami, atlet taekwondo banyak mengalami cedera otot \& tendo, serta ligament, sedangkan padda atlet judo banyak mengalami cedera ligament dan sendi. Berdasarkan berat ringannya cedera yang dialami, atlet taekwondo dan atlet judo banyak mengalami cedera ringan. Berdasarkan waktu terjadi/sifat cedera olahraga yang dialami, atlet taekwondo dan atlet judo banyak mengalami cedera kronis.

\section{PENUTUP}

\section{Kesimpulan.}

Berdasarkan hasil penelitian tentang cedera olahraga pada atlet taekwondo dan atlet judo, didapat kesimpulan sebagai berikut:

1. Atlet taekwondo yang terkena cedera olahraga ada 22 atlet $(95.65 \%)$ dari 23 jumlah atlet sedangkan pada atlet judo yang terkena cedera olahraga ada 18 atlet $(100 \%)$ dari 18 jumlah atlet.

2. Pada atlet taekwondo terdapat 92 kasus cedera olahraga dari 23 jumlah atlet, sedangkan pada atlet judo terdapat 60 kasus cedera olahraga dari 18 jumlah atlet.

3. Atlet taekwondo banyak mengalami cedera olahraga pada tubuh bagian bawah yaitu ada 66 kasus cedera $(71.74 \%)$ dari 92 jumlah kasus cedera, sedangkan pada atlet judo banyak mengalami cedera olahraga pada tubuh bagian atas yaitu ada 
40 kasus cedera $(66.67 \%)$ dari 60 jumlah kasus cedera.

4. Atlet taekwondo dan atlet judo banyak mengalami cedera olahraga pada saat latihan, yaitu pada atlet taekwondo ada 80 kasus cedera $(86.96 \%)$ dari 92 jumlah kasus cedera dan pada atlet judo ada 48 kasus cedera $(80 \%)$ dari 60 jumlah kasus cedera.

5. Atlet taekwondo dan atlet judo banyak mengalami cedera olahraga karena faktor internal violence, yaitu pada atlet taekwondo ada 62 kasus cedera $(62.40 \%)$ dari 92 jumlah kasus cedera dan pada atlet judo ada 30 kasus cedera $(50 \%)$ dari 60 jumlah kasus cedera.

6. Atlet taekwondo dan atlet judo banyak menangani cedera olahraga di poliklinik PPLP Ragunan, yaitu pada atlet taekwondo ada 80 kasus cedera $(86.96 \%)$ dari 92 jumlah kasus cedera dan pada atlet judo ada 50 kasus cedera $(83.33 \%)$ dari 60 jumlah kasus cedera.

7. Atlet taekwondo banyak mengalami cedera otot \& tendo yaitu ada 36 kasus cedera $(45 \%)$ dari 80 jumlah kasus cedera yang dibawa ke poliklinik PPLP Ragunan, sedangkan pada atlet judo banyak mengalami cedera ligament dan sendi yaitu masing-masing ada 20 kasus cedera (40\%) dari 50 jumlah kasus cedera yang dibawa ke poliklinik PPLP Ragunan.

8. Atlet taekwondo dan atlet judo banyak mengalami cedera ringan, yaitu pada atlet taekwondo ada 58 kasus cedera (72.5\%) dari 80 jumlah kasus cedera yang dibawa ke poliklinik PPLP Ragunan dan pada atlet judo ada 30 kasus cedera $(60 \%)$ dari 50 jumlah kasus cedera yang dibawa ke poliklinik PPLP Ragunan.

9. Atlet taekwondo dan atlet judo banyak mengalami cedera kronis, yaitu pada atlet taekwondo ada 46 kasus cedera (57.5\%) dari 80 jumlah kasus cedera yang dibawa ke poliklinik PPLP Ragunan dan pada atlet judo ada 29 kasus cedera (58\%) dari 50 jumlah kasus cedera yang dibawa ke poliklinik PPLP Ragunan
Saran. Berdasarkan kesimpulan diatas, maka dapat dikemukakan beberapa saran yang sekiranya bermanfaat bagi atlet taekwondo dan atlet judo di PPLP Ragunan yaitu :

1. Diharapkan kepada semua pihak yang ada dikepengurusan PPLP Ragunan untuk memberikan penyuluhan mengenai cedera olahraga, khususnya olahraga beladiri taekwondo dan olahraga beladiri judo.

2. Diharapkan kepada semua pihak yang ada di PPLP Ragunan agar memperhatikan semua atlet pada saat latihan, khususnya atlet beladiri taekwondo dan atlet beladiri judo.

3. Diharapkan semua pihak yang ada di PPLP Ragunan mengetahui kemungkinan penyebab cedera olahraga, khususnya olahraga beladiri taekwondo dan olahraga beladiri judo.

4. Diharapkan semua pihak yang ada di PPLP Ragunan mengetahui penanganan pertama cedera olahraga yang baik secara medis.

5. Diharapkan semua pihak yang ada di PPLP Ragunan untuk memperhatikan sarana dan prasarana yang dipakai pada saat latihan.

6. Pelatih dan atlet harus lebih mengetahui bagian tubuh yang sering cedera, agar dapat meminimalisir kemungkinan cedera olahraga.

\section{DAFTAR RUJUKAN}

Budi Rahardjo, Pencegahan Cedera Dan Pertolongan Pertama pada Kecelakaan (DEPDIKBUD:1992)

Hardianto Wibowo, Pencegahan dan Penatalaksanaan Cedera Olahraga.Jakarta; 1994)

J. Subroto, Teknik Beladiri Judo.U (Solo: C.V. Aneka, 2000)

Jimmy MS. Too, Teknik-teknk Taekwondo, Terjemahan PT. Creative Advertising dan Design, (Jakarta: Persatuan Taekwondo Indonesia, 1977)

Kamus Besar Bahasa Indonesia Edisi Ketiga (Jakarta: Departemen Pendidikan Nasional, 2002) 
PJSI, Judo Olahragaku-Semangatku. (Jakarta: PJSI, 1990)

Poerwardarminta, Kamus Umum Bahasa Indonesia (Jakarta: Balai Pustaka, 1976)

Rusli Lutan, Penanggulangan cedera olahraga pada anak-anak sekolah dasar. (Jakarta: Diknas, 2001)

Simon Kaihena dan Untung M. S, Diktat Pedoman Peserta Ujian Kenaikan Tingkat Sabuk Hitam/Dan Taekwondo Indonesia (Jakarta: Panitia Kenaikan Tingkat/Dan, 1966)

Yoyok Suryadi, Tae Kwon Do Pomse Tae Geuk (Yogyakarta: 2002)

http://bataviase.co.id/node/83065

http://id.wikipedia.org/wiki/Judo

http://www.Pembibitan Olahraga.org

http://www.repositori.ui.ac.id, "Kuliah Pengantar Cedera Olahraga", oleh Ade Jeanne D.L. TOBING 